\title{
A clinopyroxene record of primitive melt diversity and mantle heterogeneity beneath Italy
}

\author{
ANTOINE J. J. BRACCO GARTNER ${ }^{1,2}$, IGOR K. \\ NIKOGOSIAN $^{2,3}$, MANFRED J. VAN BERGEN ${ }^{2}$, JANNE M. \\ KOORNNEEF $^{3}$ AND PAUL R. D. MASON ${ }^{2}$ \\ ${ }^{1}$ Vrije Universiteit Amsterdam \\ ${ }^{2}$ Utrecht University \\ ${ }^{3}$ Vrije Universiteit \\ Presenting Author: a.j.j.braccogartner@vu.nl
}

The young potassium-rich volcanic rocks of peninsular Italy are the products of a complex post-collisional geodynamic setting. These volcanic rocks exhibit extreme compositional variability in space and time, resulting from large variations in the subducted material in their mantle sources. The genetic relationships between distinct Italian magmatic seriesshoshonitic, potassic, ultrapotassic and lamproitic, among others - that are closely related in space and time, as well as the exact nature and provenance of the metasomatic agents, are subject to active debate.

The earliest crystallised silicate phases from mafic lavasolivine and clinopyroxene-carry valuable information on the nature of mantle sources and melt extraction processes. Because Mg-rich clinopyroxene incorporates significant amounts of incompatible elements and is a ubiquitous phase in mafic Italian lavas, it potentially represents a versatile instrument for delineating the compositional complexity and regional variability of subduction-modified mantle sources in this region.

Here we present the results of an extensive study of Mg-rich clinopyroxene $(\mathrm{Mg} \#=88-93 \mathrm{~mol} \%)$ from potassium-rich mafic rocks from a chain of volcanic centres in central-southern Italy, from Tuscany down to Campania. We compare major- and traceelement data from clinopyroxenes with those from bulk rocks and olivine-hosted melt inclusions, using new estimates of traceelement partitioning between clinopyroxene and potassium-rich magmas based on cogenetic clinopyroxene-olivine crystallisation. The Mg-rich clinopyroxenes show a marked compositional diversity that reflects the nature of the (near)primary mantle-derived melts from which they crystallised, and allow us to characterise the metasomatic agents responsible for the formation of different compositional end-members. We demonstrate that clinopyroxenes provide a detailed archive of mantle heterogeneity beneath Italy, highlighting systematic variations both regionally and beneath individual volcanic complexes. 